\title{
Scriptural reasoning: An expression of what it means to be a Faculty of Theology and Religion
}

\begin{tabular}{|c|c|}
\hline $\begin{array}{l}\text { Author: } \\
\text { Jaco Beyers }{ }^{1}\end{array}$ & \\
\hline $\begin{array}{l}\text { Affiliation: } \\
{ }^{1} \text { Department } \\
\text { Religion and } \\
\text { Faculty of The } \\
\text { Religion, Univ } \\
\text { Pretoria, Sout }\end{array}$ & $\begin{array}{l}\text { Science of } \\
\text { lissiology, } \\
\text { logy and } \\
\text { rsity of } \\
\text { Africa }\end{array}$ \\
\hline $\begin{array}{l}\text { Research Proj } \\
\text { Project Leade } \\
\text { Project Numb }\end{array}$ & $\begin{array}{l}\text { ct Registration: } \\
\text { : J. Beyers } \\
\text { er: } 02440237\end{array}$ \\
\hline $\begin{array}{l}\text { Description: } \\
\text { This research } \\
\text { project, 'Religi } \\
\text { and Education } \\
\text { by Prof. Dr Jac } \\
\text { Programme M } \\
\text { and Religious } \\
\text { member of th } \\
\text { of Science of } \\
\text { Missiology, Fa } \\
\text { Theology and } \\
\text { University of P }\end{array}$ & $\begin{array}{l}\text { s part of the } \\
\text { on, Theology } \\
\text {, directed } \\
\text { Beyers, } \\
\text { anager: Biblical } \\
\text { ttudies and } \\
\text { Department } \\
\text { eligion and } \\
\text { culty of } \\
\text { Religion, } \\
\text { retoria. }\end{array}$ \\
\hline $\begin{array}{l}\text { Correspondin } \\
\text { Jaco Beyers, } \\
\text { jaco.beyers@ }\end{array}$ & $\begin{array}{l}\text { author: } \\
\text { ip.ac.za }\end{array}$ \\
\hline $\begin{array}{l}\text { Dates: } \\
\text { Received: } 24 \\
\text { Accepted: } 11 \\
\text { Published: } 14\end{array}$ & $\begin{array}{l}\text { pr. } 2018 \\
\text { uly } 2018 \\
\text { Aug. } 2018\end{array}$ \\
\hline $\begin{array}{l}\text { How to cite th } \\
\text { Beyers, J., } 201 \\
\text { reasoning: An } \\
\text { what it means } \\
\text { of Theology an } \\
\text { Teologiese Stu } \\
\text { Studies 74(4), } \\
\text { doi.org/10.410 } \\
\text { v74i4.5048 }\end{array}$ & $\begin{array}{l}\text { is article: } \\
\text { 3, 'Scriptural } \\
\text { expression of } \\
\text { to be a Faculty } \\
\text { d Religion', HTS } \\
\text { lies/Theological } \\
\text { 5048. https:// } \\
\text { 2/hts. }\end{array}$ \\
\hline $\begin{array}{l}\text { Copyright: } \\
\text { (C) 2018. The A } \\
\text { Licensee: AOS } \\
\text { is licensed unc } \\
\text { Creative Comr } \\
\text { Attribution Lic }\end{array}$ & $\begin{array}{l}\text { uthors. } \\
\text { S. This work } \\
\text { ler the } \\
\text { nons } \\
\text { ense. }\end{array}$ \\
\hline Read online: & \\
\hline 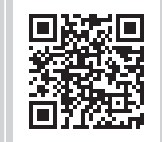 & $\begin{array}{l}\text { Scan this QR } \\
\text { code with your } \\
\text { smart phone or } \\
\text { mobile device } \\
\text { to read online. }\end{array}$ \\
\hline
\end{tabular}

During 2017, the year of its centenary celebration, the Faculty of Theology at the University of Pretoria finalised the process to change its name to the Faculty of Theology and Religion. This indicates an inclusivity and accommodative policy for all to study at the faculty. However, what does it mean to become a faculty of theology and religion at a public university in 21st century South Africa? The consequences and implications have not been thought through completely. This article does not pretend to identify all consequences of a name change but wants to contribute to the conversation by suggesting that the concept of scriptural reasoning might be one practice to be implemented as a consequence. Scriptural reasoning at a faculty of Theology and Religion, which is part of a public university in the South African context, attests to the way in which the faculty perceives its own identity. The relation between theology, religion and a public university is discussed, indicating the possibilities of implementing scriptural reasoning.

\section{Introduction}

Tertiary education in South Africa is currently experiencing challenges. Ideological, financial, social and political factors are making it increasingly more difficult to do what universities are supposed to do. Adding to this general dilemma for tertiary education is the effects of the larger social project of decolonialisation. Reflecting on the wrongs of the past in order to prevent mistakes in the future forces one to consider the structure and functioning in the present. However, constant restructuring can have the debilitating effect of stifling proper and relevant research. When the house is constantly redesigned, the inhabitants constantly contemplate identity and functionality, without really tending to the main functions required from an institution of tertiary education.

This position of liminality has also affected the Faculty of Theology at the University of Pretoria. In 2017 the centenary of the faculty was celebrated with much acclaim and flair, and rightly so. In the process of celebrating the past, a new vision for the future was created. The 'opening of the gates' as the theme of the centenary meant more than just reconfiguring the architecture of the faculty building. ${ }^{1}$ Part of the opening of the gates implied the extension of an invitation to join the faculty. From 2018 the faculty will be known as the Faculty of Theology and Religion (Fakulteit Teologie en Religie). This expanded the scope of academic engagement. The different accentuations of Reformed theology, especially in Africa, will receive more attention.

More importantly, the invitation to join the faculty also indicated that other religions would be welcome to study at the faculty. The faculty already has an established and proud history of studying other religions and the relation between Christianity and other religions. However, the pressing question is how this opening up of the faculty to other religions will work out in reality. This article attempts to provide a few suggestions in steering this process.

The accommodating of others will remain a process. Changing the name of the faculty was only the beginning of the beginning. Although what the end result will be is not clear, the direction is very clear: working towards a more inclusive, representative resemblance of society and its religious needs. En route to the realisation of this goal several possible elements may be employed. This article suggests that scriptural reasoning (SR) may be one such element that may contribute to give visible expression of what it means to be a faculty of Theology and Religion. The introduction of the concept of SR cannot be seen as a separate matter from the effort of the faculty to establish itself as being inclusive. The implications of SR have a much wider effect on the very nature and identity of the Faculty of Theology and Religion. This article will attempt to highlight

1.Compare in this regard the discussion and evaluation by Duncan (2016) of the Gateway as transformation of the Faculty of Theology at Pretoria. 
some of the essential considerations and changes that need to take place to create congruency between the new name of the faculty and its functioning.

To illuminate the complexity of the situation addressed in the previous paragraph several key concepts relevant to the debate need to be identified and discussed. The conversation is located within the discourse on proper tertiary education as well as within the debate on the relation between religion and theology. A third important meta-discourse is the inter-religious dialogue. To indicate the integration of these conversations, a discussion on public university, theology, religion and religion studies will follow. A way out of the jungle of debate will be the discussion of SR as an integrating factor contributing to the efficient functioning of the Faculty of Theology and Religion at a public university in a multireligious environment.

\section{Key concerns \\ Public university}

The University of Pretoria, where the Faculty of Theology and Religion is situated, is a state university funded by government and operating according to the national policies as accepted and implemented by the Department of Higher Education. Institutions of tertiary education have a triad of responsibilities, including serving the scientific community through doing research, providing trained professionals through teaching, and serving communities through social engagement (UP Strategic Plan 2025). In performing these responsibilities, institutions of tertiary education are contributing to the effective functioning of society and the country as a whole. Governments invest in institutions of tertiary education in order to contribute to the effective governing of society.

Institutions of tertiary education serve the community at large, without excluding any member of society from having access to tertiary education. The ideal is that the demographic constitution of society is reflected in the demographic constitution of students at institutions of tertiary education. The religious diversity in society also ought to be reflected in the constituency of students present at institutions of tertiary education. The reality is that South Africa is a religiously diverse society. The multireligious identity of South African societies includes the presence of what might be referred to as the 'unaffiliated', those members of society choosing not to form any religious affiliation. In addition, a growing number of people might be considered to have a multireligious identity, ${ }^{2}$ members of society choosing to affiliate with more than one religious affiliation simultaneously.

If this is what South African society looks like, this demographic division should be reflected in the religious identity on the campus of the University of Pretoria.

2.In this regard, compare the research conducted by Berghuijs et al. (2017). Although reflecting the results of research done in a European environment, sufficient proof
exists that the concept of multireligious identity is a universal phenomenon exists that the concept of multireligious
(Berghuijs et al. 2017; Mercadante 2017).
The University of Pretoria is a public university, funded by government. Public universities all over the world need to determine what kind of university they want to be. The teaching model at the University of Pretoria has increasingly evolved to reflect the characteristics of the traditional model of what a university's identity entails. The identity of the University of Pretoria seems to have emerged to reflect the model of the University of Berlin (1810), where a combined religious and secular character is part of the identity of the public university (Ford 2006:352). A public university needs to reflect the actual religious character of society. In this regard, the Faculty of Theology has broken with the mono-religious (and even mono-theological) orientation that reflected the colonial orientation it has had since its inception. However, a single secular ideology cannot lead to policies excluding people from studying religion at a university. A public university needs to reflect the multifaith and secular world where the majority of people are related to religious traditions (Ford 2006:352). In this regard, the Faculty of Theology and Religion has claimed a postcolonial identity of being inclusive towards other theologies and religions, although the point of departure remains a Christian perspective.

In an analysis of the possible future of theology at a university, Woltersdorff (1996) identified four distinct challenges theological education is facing today. For our discussion only two of the considerations are relevant. Woltersdorff (1996:92) firstly argues that universities want to provide general education to all its students. There is no room for particularities. Public universities do not want to specialise in any particular science or discipline. The ideal profile of a student exiting the general training at university is that of a rounded human being, trained holistically in all faculties of humanness. Universities want to prevent particularism. The South African context, as indicated earlier, is a pluralistic society consisting of diversity in terms of race, culture, language, gender and religion. This cannot be ignored. Universities in South Africa need to embrace diversity. Students ought to be prepared to cope with the reality of a diverse society. In this regard the Faculty of Theology and Religion is in line with this trajectory of thought.

Woltersdorff (1996:97) secondly reminds us that public universities serve the broader society and should in principle accommodate all religions and their theologies and, it should be added, also the non-religious. Public universities can no longer create the impression that an exclusive selection of religions to be studied has been made.

Kelsey (2009:317) indicates that in modern universities it is not only broader society that is served, but that in fact public universities serve the state. Universities train people to be able to fulfil a function in society and contribute to the well-being of all members of society. Serving the well-being of the broader society entails taking into consideration those members of society belonging to other religions or no religion. In an endeavour to be inclusive, a university cannot commit itself to exclusively favouring one religion. The purpose of the presence of religion at a university is to study religion as 
part of human behaviour in a scientific manner and not to utilise the public domain of a university as a stage for the advancement of doctrine of a particular religion. In this sense religion should be contained by the scientific restrictions set by a tertiary education institution.

The matter of the nature and desirability of theology at a university has been discussed elsewhere (see Beyers 2016a). ${ }^{3}$ The arguments for the presence of theology at a public university are assumed here. The Faculty of Theology and Religion opens up the way for members from all religions to study religion at the University of Pretoria. SR becomes one possible vehicle through which members from diverse religious affiliations will be able to participate in multireligious training.

As will become apparent in what follows, SR does have as a goal contributing to the healing of the world (Kepnes 2006:368). In this regard the tertiary education concern in the United Nations' compiled Social Development Goals can fit into the efforts by SR to contribute from a multireligious perspective to the healing of the brokenness of this world.

\section{Theology}

As to the definition of the term 'theology', Farley (1988:63) warns how the familiarity of the discussion of definitions of theology can lead to an unexciting conversation. Nevertheless, what is important for this discussion is to note, as Farley (1988:63) indicates, that the term 'theology' has a preChristian origin. The concept of theology was, according to Farley (1988:64), already present with Aristotle as well as with Plato. Christianity adopted the term to indicate the knowledge or understanding of God and the things of God. It is important to keep in mind that the term 'theology' can also be applied to non-Christian religions' attempts at reflecting on their own faith (Farley 1988:64). It would then in fact be possible to talk about Islamic theology, Buddhist theology or Jewish theology. For the sake of the discussion later on regarding Religious Studies, a distinction should be drawn here between Islamic theology (or Islamology) and Islamic studies, using Islam only as an example to illustrate the difference between the two categories. The same distinction should be applied to all religions, where an intense intrareflection is necessary as theological studies should be kept separate from a descriptive-comparative study of religions.

During the time of the rise of universities in Europe, theology came to be considered a Christian discipline worth studying academically. During the Enlightenment period, however, theology was subdivided into subdisciplines. As Farley (1983:74-75) points out, during the pre-Schleiermacher period theology consisted of four disciplines: Bible, church history, dogmatics and practical theology. In 1811, Schleiermacher discussed the nature of theology at a university again and suggested only three disciplines: scripture, dogmatics and church history (Farley 1983:89). This division, however, made provision for the theoretical disciplines (as already mentioned) and the practical disciplines. This threefold division of disciplines within theology is today still upheld by several faculties of theology. ${ }^{4}$

The debate of whether theology does indeed qualify to be named a science, worthy to be studied at a university, is a very old debate. Pannenberg (1973), and more recently McGrath (2001; 2002; 2003), have provided an extensive overview of the historical development of the arguments regarding this question. ${ }^{5}$ For McGrath, theology is the science reflecting on the God who is considered to be the creator of the natural world, on which natural sciences also focus their activities. McGrath envisages the complementarity of the two sciences. Theology must allow itself to be informed by natural sciences. Both theology and natural sciences have their own methods in approaching reality. According to McGrath, both theology and the natural sciences are a response to reality. Both must constantly assess and reflect on their results. All religions to some degree reflect on reality as it confronts human existence.

What is clear from this most recent description of the relationship between theology and natural sciences is McGrath's (2001:8) insistence on dialogue between the two disciplines. The relationship is no longer that of opposition but that of collaborative sciences. The implication to be drawn from this is to note the necessity of multidisciplinary research. Theology and the natural sciences reciprocally are in need of the other's company. In this regard the Faculty of Theology and Religion at the University of Pretoria can still expand on its existing collaborative research ties with other sciences and faculties.

By focusing on reality (nature and creation), both natural sciences and theology emphasise the importance of considering the way in which theology can contribute to and transform the whole inhabited world. Oikodome becomes a way of demonstrating the concern for the wellness of the whole created reality. The concept of oikodome plays an integral part in the way in which the Faculty of Theology perceives its role in its current context (cf. Human 2017). The faculty has envisioned its functioning in future as follows (Faculty Plan 2015):

\section{Vision}

- To be a faculty recognised for its creative engagement with life-giving theology and religious insight, of service to academia, church and community.

\section{Mission: To achieve this, we commit ourselves to}

- providing relevant theological and religious education

- nurturing transformative leaders

4.Compare in this regard the same threefold division of theology at the Faculty of Religion and Theology at the Vrije Universiteit, Amsterdam.

5.Compare Beyers (2016b) for a thorough discussion of their and others' arguments. 
- quality research

- promoting justice, peace, the integrity of creation and a reconciling diversity

- engaging people on the margins of society.

Based on this vision and mission, the faculty formulated as its faculty research theme the topic of oikodome - building up society to experience life in its fullness. In this manner, the faculty is envisaging its contribution to science as not only relevant to the scholarly community but also as transformative to the whole of society.

The test for true theology, according to Ford (2011b:3), is whether theology provides a wise answer to the cries for help in our own context. New contexts require a new search for answers. The wrestling for answers of theology is not only a wrestle with God but with reality as well (Ford 2011b:3). Theological wisdom, for Ford (2011b:4), lies in the ability to relate all reality (personal and social life; the whole of creation) to God and God's purposes. This requires creative thinking as well as relevant and credible answers in every new context. The new context for the Faculty of Theology and Religion is to establish not only an intrafaith working relationship with other Christian denominations but also an inter-religious one. Oikodome reflects the image of a house with many rooms where there is a place for all (cf. Human 2017:xxiv). In this regard the kind of scientific engagement at the Faculty of Theology and Religion reflects an openness towards others.

Ritschl (1996:35) warns about the way in which theology functions. He is very adamant that if theology is to survive as science in the new millennium it must make new contributions to science. However, he differentiates between progress (Fortschritt) and new contributions (Neues). Theology is making progress. New methods and applications are found regularly, but theology rarely comes up with something new (Ritschl 1996:36). The achievements by the different disciplines in theology, Ritschl ascribes to non-theological work. Ritschl (1996:36) is of the opinion that methods, questions, deductions and criteria implemented in subjects such as Church History and Old and New Testament Studies are not theological in nature. Many products in these disciplines are merely repetition of clichés. The conclusion Ritschl (1996:37) arrives at is that theology seems not to be a science any more. At most, theology can be considered as wisdom utilising scientific methods. This warning by Ritschl needs to be heeded in order for theology to steer clear of the trap of becoming a quasiscience. To counter this threat, theology needs to create new connections. Through a network of collaboration, theology can contribute to creating new configurations of concepts, methods and domains. Theology should bring domains into conversation with one another in order to put new answers on the table. By bringing different religions as conversation partners together, theology is creating opportunities for creating new and relevant questions as well as answers.

This is exactly what the Faculty of Theology and Religion attempts to do with a different understanding as to what constitutes science. Ritschl's definition of science is still influenced by the modernistic understanding of progression that lies on a linear development stretching from primitive towards more advanced. Something is only science, then, if it is considered as 'new' (Ritschl 1996:36). However, if science is understood according to the explanation of Karl Polanyi, a different approach to theological activities becomes apparent.

Polanyi (see Cattani 1995:67) is opposed to any dogmatism, which implies knowledge as closed and fixed. Knowledge is not subject to fixed criteria of what is considered as acceptable knowledge. Further, Polanyi's theory of science states that knowledge is considered as truth when truth is the result of testing it to the consensus of members belonging to a specific community (see Cattani 1995:66). Scientific activities therefore need not add something new to knowledge to be considered as science, as Ritschl suggests. Knowledge that is 'different' to what is accepted within a particular community can still be considered scientific. Studying the beliefs and rituals of other religions is not contradicting nor replacing theological knowledge. Addition of knowledge enhances one's understanding of reality. In this regard, by studying traditions from other religions, the faculty is adding to knowledge.

\section{Religion and religion studies}

Religion is not an entity or a field of entities but an aspect of human experience which has specific historical and cultural expressions. Religion as religiousness is the individual human being's response to what it discerns to be the most comprehensive powers of its environment. Religion as historical tradition is the corporate and symbolic expression of that discernment rendered into forms of repetition, transmission, institution. (Farley 1988:66)

The description of the concept of religion by Farley provides a good orientation as to how to understand what religion entails. As to Farley's analysis, it becomes clear that monolithic blocks or entities named 'religion' do not in fact exist. What do exist are contextual expressions of human responses to what is considered to exist outside and qualitatively above humans. It remains extremely difficult to define religion (Smith 1991:17). Braun (2000:4) and Schilderman (2014:176) concede this point. For Smith, the inadequate existing multitude of definitions for 'religion' is an indication that the term should be discarded, as it has become unusable. ${ }^{6}$ Cox (2010:3-7) suggests as alternative to the dilemma of defining religion that studying the groups of definitions has more value than studying the definitions themselves.

Defining religion is never an unbiased endeavour. The culture of the one defining always plays a role. Culture contributes to the spectacles through which religion is viewed (Smith 1991:18). For too long, Smith argues (1991:52), Western culture has determined the way religion is perceived and what can be deemed religious, as well as the relations between religion and 6.For a detailed discussion of the problem of defining religion, compare Beyers (2010:2). 
other disciplines. Western researchers have over centuries determined the field of religion by providing names for the world religions. The methods of studying religions exist mainly because of historic Western scholarly processes. As Chidester (2017:75) summarises: religion is a modern invention, a Western construction, a colonial imposition or an imperial expansion.

After carefully indicating that the concept of religion is in fact a concept originating from a Western stance of naming and analysing the human environment and behaviour, Smith comes up with a solution as to the problem of transposing the (Western) concept of religion onto world religions. Smith's (1991:50) suggestion is to discard the term 'religion' altogether. His argument remains that the term 'religion' is misleading, confusing and unnecessary. The term 'religion' hampers the understanding of people's faith and traditions. This hampering is caused by our attempt to conceptualise the faith and traditions into what we refer to as religion.

Smith (1991:53, n. 2) suggests that, instead of referring to religion, it is more appropriate to talk about 'cumulative traditions'. Traditions have contexts and history. The concept of religion tends to call to mind a structured system of beliefs. There are more words to refer to the phenomena that Western minds over time have provided with names (Smith 1991:52). Smith suggests the terms 'piety', 'reverence', 'faith', 'devotion' and 'God-fearing' as alternatives. These terms do not necessarily call to mind an organised system but do belong within the same discourse as related terms. In this regard, Chidester (2017:76) suggests that related terms should also include 'superstition' and 'magic', 'heresy' and 'infidelity', 'secularism' and 'irreligion'. The point Chidester argues is that the scope and interdisciplinary approach to the study of religion should be expanded.

The value of Smith's and Chidester's suggestions lies in the fact that the context of Religion Studies at the University of Pretoria is ambivalent. A Western-biased concept such as religion is studied at an institution of tertiary education that has historically been determined by Western principles of education on the African continent. Africa can be many things to many people, but being exclusively Western is not one of them. In an era of postcolonialism, it is necessary to think anew about the hermeneutics governing teaching and research. This is a project currently underway at the Faculty of Theology and Religion (University of Pretoria).

The problem, however, is that by completely discarding the concept of religion, the discipline of Religion Studies loses focus as to what ought to be studied. The result might be that we end up studying everything, as Chidester (2017:79) points out. Religion Studies is neither anthropology nor theology. Anthropology focuses on studying human behaviour in all its forms from a purely humanistic point of view, and Religion Studies concentrates on the spiritual behaviour of humans, without studying the transcendence to which human spiritual attention is directed, as theology would attempt. Religion Studies still studies the congealed traditions communities historically inherited from the past and apply to their own current needs. The separate belief systems and their relations are still within the scope of Religion Studies. Smith's suggestion can be employed as a method of studying the belief systems (or religions) of the world. The value of Smith's analysis lies in its view that studying a religion is not complete without taking notice of the religiosity or cumulative tradition lying at the foundation of the religious expressions. In this way Religion Studies in the Faculty of Theology still studies religion, but now in following Smith's notion it also takes heed of the religiosity underlying religious expressions and simultaneously takes heed of Chidester's suggestion of expanding the field so as to include related terminology.

The way in which Smith presents the object of study as cumulative traditions, piety or religiosity is of importance in an African context. Because the concept of religion has convincingly been proved by Smith to have a Western origin, it by default does not apply to what we want to study in an African context. Smith's suggestion for alternatives to religion is relevant to Religion Studies in Southern Africa.

By changing the name of the faculty to 'Theology and Religion', the scope is opened up to include more than just theological considerations. Spirituality and fixed (institutionalised) forms of expressions thereof are also to be included. The study of religion no longer entails only studying texts and beliefs. Chidester (2017:75), in an attempt to predict the way forward for Religion Studies, emphasises the importance of studying the material effects of religion as well. This opens the scope to include studying texts as well as investigating art, media, rituals, clothing and any other religious commodities associated with religion (cf. Chidester 2017:79).

For Wiebe (2005:99), it is important to note that Religion Studies assumes a position of investigating religion as a social phenomenon, shedding the theological cloak that others might suspect the studying of religion at a university to wear. The purpose of Religion Studies is to reach an academic and critical understanding of religious traditions without creating the perception of nurturing faith. Studying religion at the Faculty of Theology and Religion is done from a non-confessional and unbiased position. Religion Studies is then in line with the description by Wiebe (2005:99); not a faith-based study of religion as theology and religion education would attempt. There is then no instruction in religion, or as Ogden (1991:72,73) describes it, no 'propagating faith' or 'catechesis' but only teaching about religion (Wiebe 2005:100). Without the confessional bound position associated with seminaries, the scope of studying religion academically is opened up to include a wide variety of possible approaches and connections. It is in this context that Wiebe's comment (2005:98) about the impossibility to define Religion Studies as an academic discipline must be seen. On this Benson's (1987:92) description is valuable. He describes the connectedness of Religion Studies as 'disciplines gathered around the complex phenomenon of religious 
belief and practice'. In describing this multiple connectedness Chidester's (2017:79) recommendation of a multidisciplinary approach to studying religion should be heeded.

Some remarks regarding the actual implementation of combining religion and theology within a faculty of theology and religion are necessary. There seems to be a tension on the one hand between theology that is confessional determined at a public university, and on the other hand the nonconfessional study of religion. It needs to be emphasised that theology at the University of Pretoria is presented according to the third model Ogden (1991:69) suggests. The University of Pretoria is a state-run public university, as opposed to a church-run university. Ogden identifies three possible ways that theology can be accommodated at a university: churchrelated faculties can either function as 'defenders of the faith' or as 'non-affirming types' of institutions. The first type limits students in their theological reflections by prescribing a particular theological position. The second type has almost no clear theological position, resulting in absolute academic freedom, which in effect does not make it different from secular universities. Based on this, Ogden suggests a third position, which he calls the 'free Christian type of institution' (Ogden 1991:69). This position subscribes to a specific confessional position while simultaneously maintaining the autonomy of the institution and the academic freedom of the academic members. Such a position endeavours to be a church-related institution that is absolutely free and autonomous.

This third position seems to be a possibility for the Faculty of Theology and Religion at the University of Pretoria. It simultaneously guarantees the confessional bounds of the church partners who want their ministers to be trained at the faculty but also permits academic freedom to include studies of other religions. In this regard, several possible scenarios can be identified.

Scenario 1 would suggest a configuration where religion functions as a separate department within the faculty alongside all traditional or reconceived combinations of disciplines, interrelated to other disciplines as far as similarities and shared interest goes. The advantage of having a separate Department of Religion Studies is that an avenue is created dedicated to studying religions alongside other traditional disciplines, a department with its own character of approach and methodology and even containing representation of staff from different religious affiliations. The disadvantage would be that Religion Studies would be perceived as an appendage to the faculty. Its autonomy may outweigh its relatedness to other disciplines. A separate Department of Religion Studies may end up functioning almost alongside all other traditional theological disciplines.

Scenario 2 would refer to a decrease in the number of departments within the faculty where Religion Studies is included as a dimension within all the departments. No separate department dedicated to the study of religions is envisioned but rather a complete integration of disciplines.
The advantage of this scenario would be that consideration is given to how other religions would reflect on matters pertaining to any specific department. Other religions and their views are integrated with Christian reflections on academic matters. The disadvantage of such a scenario would be that the focus might be blurred to such an extent that the exclusive confessional position of theology might disappear, as Ogden (1991:69) describes happens in a too-free institution.

The end result is that a Faculty of Theology and Religion might function as an institution characterised by interreligious studies. The way in which Christianity reflects on reality is discussed alongside other religious perspectives. No position is morally or qualitatively challenged. Reflecting together increases perspectives and contribute to understanding the other without the necessity of changing one's own position. Inter-religious dialogue may lead to scenarios where representatives of different religions may reflect together on matters such as ecology, counselling or creation. These principles are essentially part of inter-religious dialogue as suggested by SR.

\section{Scriptural reasoning}

For an understanding of the concept of SR, works of three scholars in the field will suffice to provide an idea of what this concept entails. Steven Kepnes (2006), Peter Ochs (2012) and David F. Ford (2006) provide a good overview of the definition and origin of SR and the challenges it presents. ${ }^{7}$

As to a definition as to what constitutes SR, Kepnes (2006) provides some clarity:

SR is a practice of group reading of the scriptures of Judaism, Christianity, and Islam that builds sociality among its practitioners and releases sources of reason, compassion, and divine spirit for healing our separate communities and for the repair of the world. (p. 367)

However, the invitation to participate in SR is not limited to members of the Abrahamic faiths. There are examples where Buddhists and Hindus also participate in such group readings (Ochs 2012). From Kepnes (2006:367), it seems as if the goal of reading together is to socialise with people from different religions and gain insights from various scriptures in order to address the 'problems of the world'. As to the outcome of SR, Ochs (2012:20) indicates two more perspectives to be considered: dialogue and learning. Whereas Kepnes focuses on the healing of the world, Ochs and even Ford (2006:345) focus on the result of the experience as the gaining of insight, knowledge, or as Ford (2006:345) prefers to refer to it, as 'wisdom'. This wisdom (or reasoning of the heart; see Kepnes 2006:373) and insight are not restricted to understanding the 'Other', but does include critical self-evaluation and selfreflection on the own understanding of scripture.

7 This is in addition to the insights that can be gained by reading material on the website of the Society of Scriptural Reasoning (www.scripturalreasoning.org) and website of the Society of Scriptural Reasoning (www.scripturalreasoning.org) and
articles and forum discussions in the Journal of Scriptural Reasoning (available online at http://etext.virginia.edu/journal/ssr). 
The element of inter-religious dialogue does not figure as strongly with Kepnes as it does with Ochs and Ford. This might be the most important element of SR, to be able to engage with other faiths in a non-confrontational way. Ochs (2012:16) indicates that the roots of SR lie in attempts at interreligious dialogue during the late 20th century. Scriptural reasoning grew from traditional textual studies in Judaism, Christianity and Islam that were conducted in a comparative manner to provide commentary on the different texts. This included historical, literary, hermeneutical and philosophical approaches (Ochs 2012:16). Ford (2006:347) provides a detailed account of the chronology of events leading to the establishment of the SR community, resulting from a textual reasoning group chaired by Peter Ochs and David Novak in 1991 at Drew University, USA. This group became the forerunner of the SR community after Daniel Hardy and David Ford joined the textual reasoning group at the American Academy of Religion in early 1990. The textual studies were combined during the 1990s with an interest in not only the texts as representative of religions but a sincere interest in the people behind the texts. In SR studying the texts now becomes a means to a broader goal of understanding the other, learning together and seeking ways of addressing matters of social concern.

Ford (2006:348) is very clear on this matter - that the outcome of SR is not seeking consensus on determining the meaning of scriptures but rather seeking 'friendship' and 'collegiality'. The most likely outcome will be that a recognition of deep differences in the meaning of scripture is necessary. It thus becomes clear that reading the scriptures is merely a means of establishing a relationship of trust and friendship in order to be able to dialogue on more than just the text.

My assessment is that the desirability of SR is not motivated by a philanthropic (Kepnes) or academic or sociability (Ochs) factor but is a theological matter, even more precisely a theology of religions matter. We will return to this crucial matter shortly.

It is however clear that SR is not a model to be copied indiscriminately. Scriptural reasoning is a practice before it is a theory (Kepnes 2006:370). This would imply that some reflection is necessary before implementing SR in an African context at an African academic institution. When considering reading partners at a SR meeting organised at the Faculty of Theology and Religion in Pretoria, members from African traditional religions (ATRs) cannot be excluded. The immediate dilemma would be that there are no clear scriptures associated with ATRs. How do we go about dealing with this matter? As African culture traditionally tends to have been an oral culture (not excluding the huge amount of artefacts reflecting the richness of African culture), it would prove to be difficult to present scripture representing ATRs. Kepnes (2006:370) acknowledges the fact that religions contain more than scriptures as expression of religion. Symbols, rituals and doctrine captured in myths are all possibilities of carriers of meaning to be considered. African art can serve as a possible 'text' to consider for SR. Material culture such as art can in this case as material religion serve the purpose of being the text to be considered. A selection of art to be utilised may prove to be difficult, as not all affiliated to ATRs may agree on the representational value of art pieces. Through the process of SR a process of discovering a workable solution to this matter might reveal itself.

A second concern may be whom to invite to SR meetings: professionals or students? There seem to be two distinct models representing two schools of thought on this matter. The Cambridge model, reflecting the ideas of Ford (2006:348), seems to suggest that professionals (i.e. imams, rabbis and church leaders) and academic scholars should be invited to attend. The Amsterdam model, as structured after the ideas of Marianne Moyaert (2013:64), follows the route of having postgraduate students attend SR meetings as part of a formal academic programme. However, it is also clear that different opportunities will present themselves. Ford (2011a) indicates that SR meetings have already started in schools, hospitals and prisons among individuals feeling the need to dialogue with others. It seems the invitation may be constructed with a particular group of attendees in mind. However, it would be productive to invite a homogeneous group, consisting of either scholars or students.

In summary, the goals of SR can be formulated as follows:

- finding wisdom from scriptures to contribute to the healing of the brokenness of the world

- building inter-religious relations by way of converting collegiality to friendship

- creating mutual respect and understanding among religions

- enhancing interpretation, understanding and meaning of scriptures.

\section{Argument for the case of scriptural reasoning}

Some important considerations to take note of, prior to implementing SR, would be the following.

\section{Clarifying theology of religions}

Although Kepnes (2006:379) indicates that mutual respect is a prerequisite among members at a SR meeting, something more is needed than mere good manners. Underlying the motivation to engage in SR lies a theological orientation.

One might suspect that SR is based on John Hick's concept of pluralism, where all religions are viewed theologically to be of equal value and to contain equal truth. Knitter's (2005) suggestion of three traditional models of theologies of religions would suggest that inclusivity and exclusivity would constitute the two other models in addition to Hick's pluralistic model. The inclusive and exclusive models of theology of religions come down to dialogue with an agenda: although acknowledging that revelation is possible through 
all religions (inclusivity), Christianity is still the only religion through which salvation is possible (exclusivity).

Hick (1989:235-236) states that all religions are cultural interpretations of what all agree to be God (reflecting an essential theocentrism, postulating one ultimate reality). All religions have access to salvation by their own unique way. Pluralism seeks similarities and commonalities and thereby leads to a relativising of all religious convictions. Interreligious dialogue has the purpose of identifying similarities and relativising differences.

Moyaert (2013:66), however, argues that SR reflects a 'postliberal particularism', acknowledging and preserving the unique identity of each religion (Kepnes 2006:372). Scriptural reasoning does not seek commonalities or 'consensus' (Ford 2006:347) but acknowledges the particularity of each religion (Moyaert 2013:66). Only by respecting the sacredness of the scriptures of the other without accepting it as authority for oneself (Ford 2006:348) is true, open and non-threatening dialogue possible. The trajectory of thought indicated by Moyaert and Ford is the way in which SR will be conducted at the University of Pretoria. Once a theological position on a theology of religions has been determined, engaging with other religions in SR is possible.

\section{Acknowledging different hermeneutics}

The hermeneutical process is not an unbiased process. It is necessary to acknowledge the particular hermeneutical position from which one participates in discussing scripture as well as acknowledging the possibility that the other participants may also be correct in their interpretation. There are several hermeneutical positions that need to be recognised. The intention here is not to provide an extensive list of all possible hermeneutical positions but rather to create awareness of the presence of such perspectives.

When approaching texts from a fundamentalist position, readers may expect to find nothing but the word of God in the scripture. The result might be that no alternative interpretation of scripture is possible. The meaning of the text is perceived to have been historically determined and no other meaning is possible. This hampers discussion and conversation about the meaning of the text.

Another approach might be the historical-critical reading of texts, emphasising the text itself without considering the possibility of reaching meaning through a subjective reading. The text with its meaning as it was intended by the writer for the first readers to find is considered the ultimate meaning of the text.

It is important for participants in SR to acknowledge the own context from which one reads. Ricoeur (2017 [1981]:219) emphasises that meaning is not behind the text, nor in the text structure, but rather is found in front of the text. It therefore becomes important for participants in SR to recognise their own hermeneutical position from which they read, whether it be a feminist, post-liberal, postcolonial or even fundamental or historical-critical position. The position of reading determines the meaning arrived at.

\section{Dealing with multiple meanings of texts}

It is important to realise that SR is an exercise in seeking meaning of the scriptures. However, meaning is not a simple matter. The purpose of SR is not to arrive at a point of consensus (Ford 2006:347) on the meaning of scripture, as if only one meaning can be derived from a text.

Kepnes (2006:374) reminds us that the very origin of SR is textual study. So meaning is first of all concerned with 'the plain sense meaning' of scripture. This kind of meaning is derived from investigating language and grammar in the text. However, reasoning is also concerned with the theological meaning of scripture (Kepnes 2006:374). To arrive at meaning often hidden in the texts, certain processes of interpretation are necessary.

Kepnes (2006:374) and Ochs (2012:22) indicate that SR draws on the semiotic theory of Charles Pierce. According to Pierce, a process of hermeneutics involves three parts: a sign (word), meaning, and a context (Ochs 2012:22). Meaning is therefore dependant also on context. This requires a process of seeking meaning within every new time and place (context). Meaning is not fixed (Ochs 2012:25) or locked in the past (Kepnes 2006:375). This enables others to comment on scriptures in search of meaning within a particular context by challenging the text with new questions. The result is that participants in SR can contradict one another in terms of differing contexts from which each participant speaks. Ochs (2012:25) indicates that dealing with multiple meanings is not a conflict of meaning. Different meanings do not contradict but merely differ. Contrariety is not contradiction (Ochs 2012:26). Kepnes (2006:376) refers to these multiple meanings as provisional.

What is important to see is that the willingness to accept a multitude of provisional meanings to texts steers the discussion away from liberal and fundamental reading of scripture. Scriptural reasoning seeks a position of tolerance, not subscribing to secularism or fundamentalism (Kepnes 2006:380). The end result is not a determining of true or false meaning but rather a willingness and openness to consider what Ford (2006:364) refers to as 'analogous wisdom', meanings existing parallel to one another, enhancing the understanding of one another and the text.

\section{Practical applications}

In terms of practical arrangements for a SR meeting, Kepnes (2006) provides a detailed map. What follows here is an abbreviated suggestion as to how a SR session can be arranged practically.

Choose appropriate texts: There do exist several examples of previous SR meetings where a lot of consideration was given 
as to which scriptures to read. The website of the Society of Scriptural Reasoning does provide resources for this purpose. Kepnes (2006:382) indicates that topics to consider for texts might be texts surrounding particular figures like Abraham, Adam or Moses. Themes to be considered include hospitality, gender, creation, sacrifice, usury, clothing, healing, ecology and violence. Texts from Jewish, Christian and Muslim backgrounds relating to these topics can be selected.

Select a proper venue: It would be best to decide on a neutral environment where all will feel comfortable to meet. There should be sufficient space to accommodate the group, which should consist of between 6 and 30 members. Additional rooms for breakaway sessions may facilitate discussions.

Decide on the time spent: Kepnes (2006:382) stresses the importance of not rushing the discussions. He suggests that four sessions of $2 \mathrm{~h}$ each will be sufficient per topic. For a more formal academic programme, Moyaert suggests six interactive gatherings of $2.5 \mathrm{~h}$ each. Each session must have a clear goal. Moyaert suggests the following agenda for the sessions:

- Reflect on the context from which participants speak and how their context affects their reading.

- Discuss different reading strategies and identify how each reading brings new interpretations and meaning to the surface.

- Express your own reading and how it connects to your context and explain it to others.

- Express how the reading of text together with others affects your own understanding of the text and understanding of the others.

The formal programme is concluded by students completing and submitting for assessment a written assignment based on the elements for reflection stated above.

Select a facilitator: The function of the facilitator is not to steer the conversation but merely to act as reminder on what the purpose of the gathering is. The facilitator needs to be someone familiar with the concept of SR and must be able to see to it that the participants engage in a manner respecting the others and allowing equal opportunities for conversation. In the model followed by Moyaert, a senior student (teaching assistant) is appointed as facilitator to prevent the conversation being dominated by a senior academic scholar.

Setting up house rules: The conversation should be conducted following certain rules. Equal opportunity for all to participate and express their views in a non-threatening way should be allowed. In the model Moyaert follows, the group participants during the first meeting set up the rules themselves and agreement is reached on how the group will deal with transgressions.

\section{Implications and conclusion}

By implementing SR as practice within the Faculty of Theology and Religion, expression can be given to the intention of the change of name of the faculty. No longer is only one religion or only one theological position welcomed, but a true openness towards other religions and theological accentuations is promoted. This, in effect, will enhance inter-religious studies, a position enabling Theology and Religion Studies to coexist in one faculty within the domain of a public university.

The principle of inter-religiosity can even spill over into restructuring the faculty. Consideration can be given to restructuring the faculty to consist of only three departments: Department of Texts and Beliefs (scriptures, systematics and religions), Department of History (philosophy of religion, church and mission history) and Department of Practices (counselling, liturgy and missiology). This would be following the line of thought already suggested by Schleiermacher in the early 19th century, as Farley (1983:84) has indicated.

The effect of a name change for the faculty implies an openness, as well as an extension of inclusivity. However, inclusivity knows no limit. This would imply that the faculty will need to seek more church partners as well as more religions willing to collaborate in the academic endeavour. This creates integrity, as diversity strengthens credibility. Academic activities and the results thereof will reflect the reality of a multireligious and multifaith society. Diversity forces all parties to reaffirm their identities. Account should be given by each participant in the Faculty of Theology and Religion as to why he or she believes this and not that. Diversity is not a threat but an opportunity for selfaffirmation. Ford (2006:352) emphasises the interfaith as well as intrafaith dimensions of SR.

Through inter-religious studies and inter-religious dialogue, social cohesion can be achieved. Studying religions contributes to the understanding and functioning of society at large. Through creating opportunities for representatives of all religions and no religions to meet and converse, the Faculty of Theology and Religion stimulates interaction and dialogue.

By implementing SR as practice to give expression to what it means to be a Faculty of Theology and Religion, the faculty will express its commitment to academic excellence. SR has not yet been implemented as an academic endeavour at any university in South Africa. By implementing the practice of SR, the faculty will be creating a centre of expertise inviting anyone in need of advice on inter-religious relations and the relation of religion and theology to consult the Faculty of Theology and Religion at the University of Pretoria.

\section{Acknowledgements Competing interests}

The author declares that he has no financial or personal relationships which may have inappropriately influenced him in writing this article. 


\section{References}

Benson, T.L., 1987, 'Religious studies as an academic discipline', in M. Eliade (ed.), Encyclopaedia of religion, vol. XIV, pp. 88-92, MacMillan Press, New York.

Berghuijs, J., Kalsky, M., Van der Braak, A.F.M. \& Oostveen, D.F., 2017, 'Aspecten van belonging in Multiple Religious Belonging', Psyche en Geloof 28(2), 79-99.

Beyers, J., 2010, 'What is religion? An African understanding', HTS Teologiese Studies/ Theological Studies 66(1), Art. \#341, 1-8. https://doi.org/10.4102/hts.v66i1.34

Beyers, J., 2016a, 'Theology and higher education: The place of a Faculty of Theology at a South African University', HTS Teologiese Studies/Theological Studies 72(4), a3450. https://doi.org/10.4102/hts.v72i4.3450

Beyers, J., 2016b, 'How scientific is theology really? A matter of credibility', HTS Teologiese Studies/Theological Studies 72(4), a3449. https://doi.org/10.4102/hts. v72i4.3449

Braun, W., 2000, 'Religion', in W. Braun \& T. McCutcheon (eds.), Guide to the study of religion, pp. 3-18, Cassell, London.

Buitendag, J., 2014, 'Between the Scylla and the Charybdis: Theological education in the 21st century in Africa', HTS Teologiese Studies/Theological Studies 70(1), Art. \#2855, 1-5. https://doi.org/10.4102/hts.v70i1.2855

Buitendag, J., 2016, 'The idea of the university and the "Pretoria Model" Apologia pro status Facultatis Theologicae Universitatis Pretoriensis ad secundum saeculum HTS Teologiese Studies/Theological Studies 72(4), Art. \#4366. https://doi.org/ 10.4102/hts.v72i4.4366

Buitendag, J. \& Simut, C.C., 2017, 'Teaching theology at African public universities as decolonisation through education and contextualisation', HTS Teologiese Studies/ Theological Studies 73(1), Art. \#4806. https://doi.org/10.4102/hts.v73i1.4806

Cattani, A., 1995, 'Popper, Polanyi and the notion of rationality', in J. Misiek (ed.), The problem of rationality in science and its philosophy, pp. 65-74, Kluwer Academic problem of rationality
Publishers, Dordrecht.

Chidester, D., 2017, 'Beyond religious studies? The future of the study of religion in a multidisciplinary perspective', Journal for Theology and the Study of Religion 71(1), 74-85.

Cox, J.L., 2010, An introduction to the phenomenology of religion, Continuum Publishing Group, New York.

Duncan, G.A., 2016, 'Gateway to the future ... oopmaak van die hekke ... Transformation in the Faculty of Theology, University of Pretoria', HTS Teologiese Studies/ Theological Studies 72(4), https://doi.org/10.4102/hts.v72i4.3424

Faculty Plan 2015, viewed 20 June 2018, from https://www.up.ac.za/en/faculty-oftheology-and-religion/article/33422/vision-and-mission

Farley, E., 1983, Theologia: The fragmentation and unity of theological education, Fortress Press, Philadelphia, PA.

Farley, E., 1988, The fragility of knowledge: Theological education in the church \& the university, Fortress Press, Philadelphia, PA.

Ford, D.F., 2006, 'An interfaith wisdom: Scriptural reasoning between Jews, Christians and Muslims', Modern Theology 22(3), 345-366. https://doi.org/10.1111/j.14680025.2006.00322.x

Ford, D.F., 2011a, 'Jews, Christians and Muslims meet around their scriptures: An inter-faith practice for the 21st century', in The Fourth Pope John Paul II Annual Lecture on Inter-Religious Understanding. The pontifical University of St. Thomas Aquinas 'Angelicum' with the Russell Berrie Foundation, Rome, April 5.
Ford, D.F., 2011b, The future of Christian theology, Wiley-Blackwell, Sussex.

Hick, J., 1989, An interpretation of religion: Human responses to the transcendent, Yale University Press, New Haven, CT.

Human, D.J., 2017, 'Foreword', Ecodomy - Life in Its Fullness, Verbum et Ecclesia Suppl. 1, 38(3), a1728. https://doi.org/10.4102/ve.v38i3.1728

Kelsey, D.H., 2009, 'Theology in the university: Once more with feeling', Modern Theology 25(2), 315-327. https://doi.org/10.1111/j.1468-0025.2008.01521.x

Kepnes, S., 2006, 'A handbook for scriptural reasoning', Modern Theology 22(3), 367-383. https://doi.org/10.1111/j.1468-0025.2006.00323.x

Knitter, P.F., 2005, Introducing theologies of religions, Orbis Books, New York.

McGrath, A.E., 2001, A scientific theology: Nature, vol. 1, William Eerdmans, Grand Rapids, MI.

McGrath, A.E., 2002, A scientific theology: Reality, vol. 2, William Eerdmans, Grand Rapids, MI.

McGrath, A.E., 2003, A scientific theology: Theory, vol. 3, William Eerdmans, Grand Rapids, MI.

Mercadante, L., 2017, 'How does it fit? Multiple religious belonging, scriptural but not religious, and the dances of universal peace', Open Theology 3, 10-18. https://doi. org/10.1515/opth-2017-0002

Moyaert, M., 2013, 'Scriptural reasoning: Reading sacred scripture under one tent', in C. Cornille (ed.), The Wiley-Blackwell companion to interreligious dialogue, pp. 64-86, Wiley-Blackwell, Chichester.

Ochs, P., 2012, 'An introduction to scriptural reasoning: From practice to theory', Journal of Renmin University of China 26(5), 16-22.

Ogden, S.M., 1991, 'Theology in the university: The question of integrity', in D.R. Griffen \& J.C. Hough (eds.), Theology and the university: Essays in honor of John B. Cobb, Jr., pp. 67-79, State University of New York Press, New York.

Pannenberg, W., 1973, Wissenschaftstheorie und Theology, Suhrkamp Verlag, Frankfurt am Main.

Ricoeur, P., 2017 [1981], Hermeneutics and the human sciences: Essays on language, action and interpretation, transl. J.B. Thompson, Cambridge Philosophy Classics, Cambridge.

Ritschl, D., 1996, 'Gibt es in der Theologie "Neues"?', in C. Krieg, T. Kucharz \& M. Volf (eds.), Die Theologie auf dem Weg in das dritte Jahrtausend: Festschrift für Jürgen Moltmann zum 70. Geburtstag, pp. 33-43, Gütersloher Verlagshaus, Gütersloh.

Schilderman, H., 2014, 'Defining religion: A humanities perspective', in H. Schilderman (ed.), The concept of religion: Defining and measuring contemporary beliefs and practices, pp. 176-198, Brill, Leiden.

Smith, W.C., 1991, The meaning and end of religion, Fortress Press, Minneapolis, MN.

UP Strategic Plan 2025, viewed 08 February 2018, from http://www.up.ac.za/en/ about-up/article/258177/strategic-plan-2025

Wiebe, D., 2005, 'Religious studies', in J.R. Hinnells (ed.), The Routledge companion to the study of religion, pp. 98-124, Routledge, London.

Woltersdorff, N., 1996, 'Die Mühsal der Theologie in der modernen Universität', in C. Krieg, T. Kucharz \& M. Volf (eds.), Die Theologie auf dem Weg in das dritte Jahrtausend: Festschrift für Jürgen Moltmann zum 70. Geburtstag, pp. 35-46, Gütersloher Verlagshaus, Gütersloh. 